\title{
Massive strandings of pleustonic Portuguese Man-of-War (Physalia physalis) related to ENSO events along the southeastern Pacific Ocean
}

\author{
Antonio Canepa ${ }^{1}$, Jennifer E. Purcell ${ }^{2}$, Pablo Córdova ${ }^{1,3}$, Miguel Fernández ${ }^{1}$ \& Sergio Palma $^{1}$ \\ ${ }^{1}$ Escuela de Ciencias del Mar, Pontificia Universidad Católica de Valparaíso, Valparaíso, Chile \\ ${ }^{2}$ Biology Department, Western Washington University, Bellingham, Washington, USA \\ ${ }^{3}$ Servicio Hidrográfico y Oceanográfico de la Armada, Valparaíso, Chile \\ Corresponding author: Sergio Palma (sergio.palma@pucv.cl)
}

\begin{abstract}
Blooms of stinging pelagic cnidarians have been causing increasing health problems for humans worldwide. Physalia physalis is among the worst stinging species in the Atlantic and Pacific oceans along the North and South American coasts. This siphonophore species has a large gas float and lives at the ocean surface, where its distribution is affected mainly by winds. P. physalis's strandings were observed in the southeastern Pacific Ocean for three consecutive years (2014 to 2016). Data of stranded P. physalis were gathered daily through a collaborative effort between the Chilean Navy and the Chilean Ministry of Health. The association between oceanographic variables and the stranded $P$. physalis was assessed using a generalized additive mixed model (GAMM) and cross-correlation analysis. The largest stranding occurred along more than $2600 \mathrm{~km}$ of coastline and totaled 44,683 colonies. Most of the strandings were along the central and south-central coast of Chile, where almost 200 people were stung, and more than 120 beaches were closed in summer 2016. The GAMM model showed that the oceanographic conditions of warmer temperatures during the winter periods and the weakening of the westerly winds associated with the Niño Southern Oscillation (ENSO) were the most likely causes for the arrival of transport from the colonies to the coast. Also, our analysis illustrates the utility of collaborations among scientists and public organizations to promote large-scale and long-term understanding and provide a model for predicting this dangerous species' arrival and warning for beaches and swimmers, which is of global importance for human health.
\end{abstract}

Keywords: Physalia physalis; jellyfish; siphonophores; GAMM; El Niño Southern Oscillation; southeastern Pacific Ocean

\section{INTRODUCTION}

The massive proliferation of gelatinous zooplankton generates negative impacts on natural ecosystems (e.g., the Benguela Current Marine Ecosystem) and on several human activities (e.g., fisheries, tourism, aquaculture, energy power supply) (Purcell \& Arai, 2001; Mianzan et al., 2012; Canepa et al., 2014). Even though some marine ecosystems may be undergoing a long-term increase of jellyfish proliferations (i.e., Mediterranean Sea), historical data lack to conclude that a global increase of gelatinous zooplankton has occurred (Brotz et al., 2012; Condon et al., 2012). Several factors have contributed to the paucity of data on gelatinous zooplankton: they have not targeted species in fisheries or oceanographic research, they were poorly known by the scientists and considered ecologically unimportant, their fragility makes many unrecognizable after collection by standard sampling methods (but see Licandro et al., 2010). Thus, a nonscientific collection of data is important to study jellyfish populations' spatio-temporal dynamics (Purcell, 2009). More recently, citizen science has expanded the scope of data from stranded jellyfish (Houghton et al., 2007; Bernard et al., 2011; Baumann \& Schernewski, 2012; Fleming et al., 2013; Canepa et al., 2014; Purcell et al., 2015). Among stranded jellyfish, most are in Scyphozoa and Hydrozoa's classes, in which are the pleustonic species Velella velella, Porpita porpita, and Physalia physalis (Graham et al., 2001). These hydrozoans are all considered colonial and are mostly affected by winds because they have morphological adaptations (i.e., the sails) extending above the water's surface.

Physalia physalis (Portuguese Man-of-War) is recognized as a cosmopolitan species that inhabit tropi- 
cal to temperate waters from $51^{\circ} \mathrm{N}$ to $38^{\circ} \mathrm{S}$ globally (Mapstone, 2014). As other members of the Phylum Cnidaria, P. physalis has stinging cells (cnidocysts) with toxins that are powerful enough to harm humans seriously (Burnett et al., 1994; Cegolon et al., 2013; Haddad Jr. et al., 2013; Mapstone, 2015), although they rarely cause death (see Prieto et al., 2015). The colonies accumulate in convergences, where they feed mostly on fish larvae, which constituted $73.5 \%$ of their prey items, and other soft-bodied prey (Purcell, 1984), but sometimes they are washed ashore by prevailing winds and surface currents (Bingham \& Albertson, 1974; Graham et al., 2001).

Stranded $P$. physalis colonies are commonly found along the South Pacific Ocean (Pontin et al., 2011; Pontin \& Cruickshank, 2012; Oliveira et al., 2016). Reports on stranded colonies of $P$. physalis along the southeastern Pacific Ocean (SEPO) have been scarce in the past, showing sporadic events of isolated colonies. Thus, Fagetti (1958) reviewed the historical records pointing out the first records for the SEPO from Molina (1782) and Leloup (1935), who reported stranded colonies in south-central Chile and Easter Island, respectively. From 1990 to 1993, high numbers of stranded colonies were reported in central Chile during the summer when more than 230 people were stung (reviewed in Brito, 2002).

Many environmental factors may determine the size and locations of gelatinous zooplankton blooms. Factors including light, temperature, salinity, and food, may stimulate benthic stages (i.e., polyps) to produce new jellyfish (e.g., Purcell et al., 2012). Because pleustonic species like P. physalis and Velella velella are colonies with the polyps attached to the same colony, those environmental factors could also affect their asexual and sexual reproduction, although that hypothesis has not been tested yet. Additional factors, including currents, stratification, fronts, bottom topography, and wind, determine where the jellyfish will occur (Graham et al., 2001).

Three years of $P$. physalis's massive strandings along the Chilean coast at the southeastern Pacific Ocean provided the opportunity to analyze the oceanographic conditions associated with the spatiotemporal variability of the strandings group.

\section{MATERIALS AND METHODS}

\section{Physalia physalis data}

Historic reported strandings (Table 1) happened during spring or summer and were possibly associated with ocean conditions related to El Niño Southern Oscillation (ENSO) events (Brito, 2002; Araya et al.,
2016). In this study, the data of Physalia physalis arrivals to the coast between 2014 until 2016 were gathered through a monitoring program based on the collaborative effort between more than 20 Chilean Navy port captaincies and the Chilean Ministry of Health, which represents a citizen science database. The Chilean Navy inspects beaches along the coast all year long, performing daily surveys. During autumn 2014, several reports of stranded P. physalis colonies along the northern part of Chile were recognized as a public concern by the Chilean Ministry of Health. Thus, the reports of the number of stranded colonies per beach and people affected (stung) per beach, collected by the Chilean Navy along the whole Chilean territory were sent to and confirmed by the Chilean Ministry of Health and then sent to the gelatinous zooplankton ecology group (GelChile) at the Pontifical Catholic University of Valparaiso, for further analysis. During the surveys, the arrivals of $P$. physalis colonies to the coast were characterized as a stranding event, and all the stranded colonies were then removed from the beaches to avoid beachgoers being stung, which also eliminated possible recounting of the same stranded colonies over time (Fig. S1c). Only reliable data (e.g., confirmed sightings, abundance, geographical position, and date) were used.

\section{Environmental data}

Oceanographic (i.e., sea surface temperature (SST) and currents) and meteorological (i.e., wind) data were obtained to inspect the oceanographic conditions during the massive arrivals of $P$. physalis along the Chilean coast. SST and wind data were accessed through the Earth System Research Laboratory (ESRL) of the Physical Sciences Division (PSD) from NOAA (available from http://www.esrl.noaa.gov/psd/). SST data with a spatial resolution of 1.0 degree (latitude $\times$ longitude) were obtained weekly from the NOAA Optimum Interpolation (OI), available from [http:// www.esrl.noaa.gov/psd/data/gridded/data.noaa.oisst.v 2.html]. Wind data from the National Center for Environmental Prediction Reanalysis Information (NCEP/NCAR re-analysis 1) had a 0.25 degree and daily spatio-temporal resolution. A climatological series from 1981 until 2010 was used to characterize the anomalies associated with SST and wind data. Current data were obtained from the NASA Physical Oceanography Data Center (PODAAC), corresponding to the Ocean Surface Current Analyses Real-time (OSCAR) project (available from http://www.esr.org/ oscar_index.html), with a spatial resolution of 0.25 degree (latitude $\times$ longitude) and weekly frequency. A climatological series ranging from 1993 until 2012 was used to characterize current anomalies. The decomposition between zonal and meridional components 
Table 1. Reports of colonies of Physalia physalis during spring and summer from the southeastern Pacific Ocean.

\begin{tabular}{|c|c|c|c|}
\hline Location & Year & Colonies (n) & Reference \\
\hline Easter Island & 1958 & 3 & Fagetti (1958) \\
\hline Easter Island & 1972 & 2 & Moyano \& Valdovinos (1984) \\
\hline Central Chile $\left(33^{\circ} 04^{\prime} \mathrm{S}\right)$ & 1982 & 2 & Moyano \& Valdovinos (1984) \\
\hline South Chile (39²48'S) & 1984 & 204 & Moyano \& Valdovinos (1984) \\
\hline 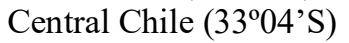 & 2002 & hundreds & Brito $(2002)$ \\
\hline North Chile (22³3’S) & 2004 & few & Vera et al. (2004) \\
\hline North Chile $\left(27^{\circ} 10^{\prime} S\right)$ & 2015 & 62 & Araya et al. (2016) \\
\hline
\end{tabular}

was performed previously to analyze the current and wind anomalies data. Thus, positive anomalies in the zonal component reflect an eastern net flow, and positive anomalies in the meridional component reflect a net flow to the north. To homogenize the spatiotemporal resolution and to collect environmental information not influenced by local/coastal processes, a specific area for SST $(2,995 \times 191 \mathrm{~km})$, wind $(10,002 \times 353 \mathrm{~km})$, and current $(3,106 \times 159 \mathrm{~km})$ were selected parallel to the coast and data were averaged for each stranding latitude and date.

Physalia physalis and environmental databases were compared using a cross-correlation analysis through the $c c f$ function (R Core Team, 2017). For this analysis, the environmental database was transformed by selecting those records that only matched in time and space with the $P$. physalis database to have the same temporal and spatial resolution. The "normalized" cross-correlation analysis was applied to different (up to 30 days) time lags at one latitudinal degree to determine maximum correlations between the environmental variables and the stranded colonies throughout the study area. Our analysis approach closely followed that of Box et al. (2005).

Finally, the stranded Physalia physalis colonies' relationship with the oceanographic data was modeled using a generalized additive mixed models (GAMM) using the gamm function from the mgcv package for $\mathrm{R}$ (Wood, 2004). Due to the high numbers of zeroes, the error family distribution used was a negative binomial distribution with a log-link to avoid predicting negative numbers of stranded colonies (Zuur et al., 2014). The mixed part of the model contained an autoregressive moving average (ARIMA) autocorrelation structure inside the model to avoid temporal autocorrelation issues (Zuur et al., 2014). R-squared and Akaike Information Criteria (AIC) were used as the model goodness of fit, and the significance of each descriptive term was assessed through the maximum likelihood with an alpha value of 0.05 . The oceanographic (anomaly series) data used to model the stranded jellyfish data was lagged previous the analysis at the maximum correlation lag found according to the crosscorrelation analysis (see the previous section). All the statistical analyses were performed using the statistical programming language $\mathrm{R}$ (R Core Team, 2017).

\section{RESULTS}

\section{Spatio-temporal distribution of Physalia physalis strandings}

A total of 44,683 stranded $P$. physalis colonies were recorded along the SEPO between May 2014 and March 2016 (Table 2). The strandings in 2015 represented the northern- and southernmost records of $P$. physalis stranded in Chile $\left(18^{\circ} 26^{\prime} 44.09^{\prime \prime} \mathrm{S}\right.$ and $42^{\circ} 37^{\prime} 59.9^{\prime \prime S}$, respectively), covering 24 degrees latitude (Fig. 1a). Although the number of reports increased from 2014 to 2016 (139 to 428), the most stranded colonies per beach $(31,522)$ and the most stranding events per beach $(2,780)$ were in 2015 . The Chilean coast (between 25 and $36^{\circ} \mathrm{S}$ ) received most of the strandings events during the three years (Table 2, Fig. 1a). Also, oceanic islands reported stranded colonies of P. physalis in 2014 and 2015 (Easter Island: 102 and 170, Robinson Crusoe Island: 51 and 6).

Colonies of $P$. physalis were stranded almost continuously after May 2014 (Fig. 1a). The earliest reports of stranded occurred during late autumn (May) in 2014 along the northern coast of Chile; however, the highest densities of stranded colonies were recorded only during late winter - early spring (July-October) along the south-central part of Chile (Fig. 1b). Some reports persisted through the summer (DecemberMarch) until winter-early spring of 2015 (JuneSeptember), when both the numbers of records and colonies stranded per beach increased to two peaks with more than 2,000 colonies per beach (Fig. 1b). The reports were concentrated in the summer season (January-March) during 2016, although in much lower magnitude (colonies per beach) than in previous years (Fig. 1b). The stranding pattern differed among the three years of massive arrivals; during 2014, colonies stranded from north to south, whereas during 2015 and 
Table 2. Numbers of stranded Physalia physalis colonies along the south-eastern Pacific Ocean. Only geopolitical regions with permanent surveys are indicated.

\begin{tabular}{lcccc}
\hline \multirow{2}{*}{ Region } & \multirow{2}{*}{ Latitude $(\mathrm{S})$} & \multicolumn{3}{c}{ Stranded colonies of $P$. physalis } \\
\cline { 3 - 5 } & & 2014 & 2015 & 2016 \\
\hline Arica-Parinacota & $18^{\circ} 28^{\prime} 30^{\prime \prime}$ & 18 & 1 & 0 \\
Tarapacá & $20^{\circ} 17^{\prime} 00^{\prime \prime}$ & 0 & 125 & 0 \\
Antofagasta & $23^{\circ} 38^{\prime} 39^{\prime \prime}$ & 54 & 528 & 0 \\
Atacama & $27^{\circ} 22^{\prime} 00^{\prime \prime}$ & 200 & 11,220 & 324 \\
Coquimbo & $29^{\circ} 54^{\prime} 28^{\prime \prime}$ & 0 & 348 & 122 \\
Valparaíso & $33^{\circ} 03^{\prime} 47^{\prime \prime}$ & 6,877 & 16,505 & 2,805 \\
O’Higgins & $34^{\circ} 22^{\prime} 19^{\prime \prime}$ & 29 & 32 & 319 \\
Maule & $35^{\circ} 25^{\prime} 36^{\prime \prime}$ & 5 & 0 & 195 \\
Bío-Bío & $36^{\circ} 46^{\prime} 22^{\prime \prime}$ & 1,998 & 2,463 & 134 \\
La Araucanía & $38^{\circ} 54^{\prime} 00^{\prime \prime}$ & 0 & 0 & 39 \\
Los Ríos & $39^{\circ} 48^{\prime} 30^{\prime \prime}$ & 12 & 70 & 0 \\
Los Lagos & $41^{\circ} 28^{\prime} 18^{\prime \prime}$ & 30 & 230 & 0 \\
\hline Total & ---- & 9,223 & 31,522 & 3,938 \\
\hline
\end{tabular}

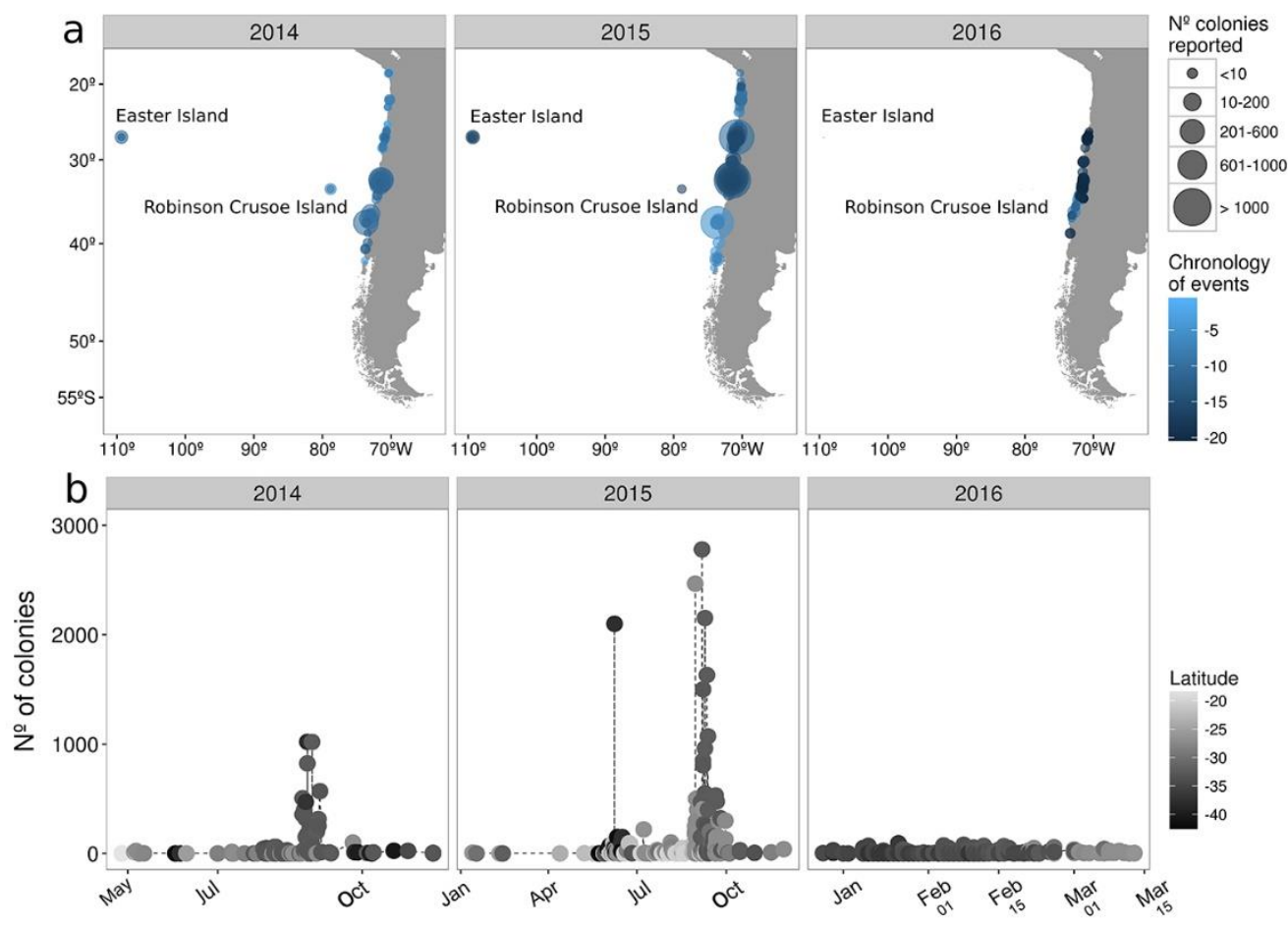

Figure 1. Spatio-temporal distribution of stranded Physalia physalis colonies along the southeastern Pacific Ocean. a) Spatial distribution of stranded colonies from 2014 to 2016. The number of colonies reported (abundance) is shown in a categorical size scale and when the colonies were reported (chronology of events) in a continuous color scale. b) Temporal distribution of stranded colonies from 2014 to 2016. The latitude of events is highlighted on a greyscale.

2016, the colonies arrived first to the south and progressed to the north (Fig. 1).
Oceanographic and meteorological conditions associated with the stranding events

Analysis of the weekly SST anomaly $\left({ }^{\circ} \mathrm{C}\right)$ showed several warmer- and cooler-than-average periods along the SEPO (Fig. 2). During January-February 2014, a 


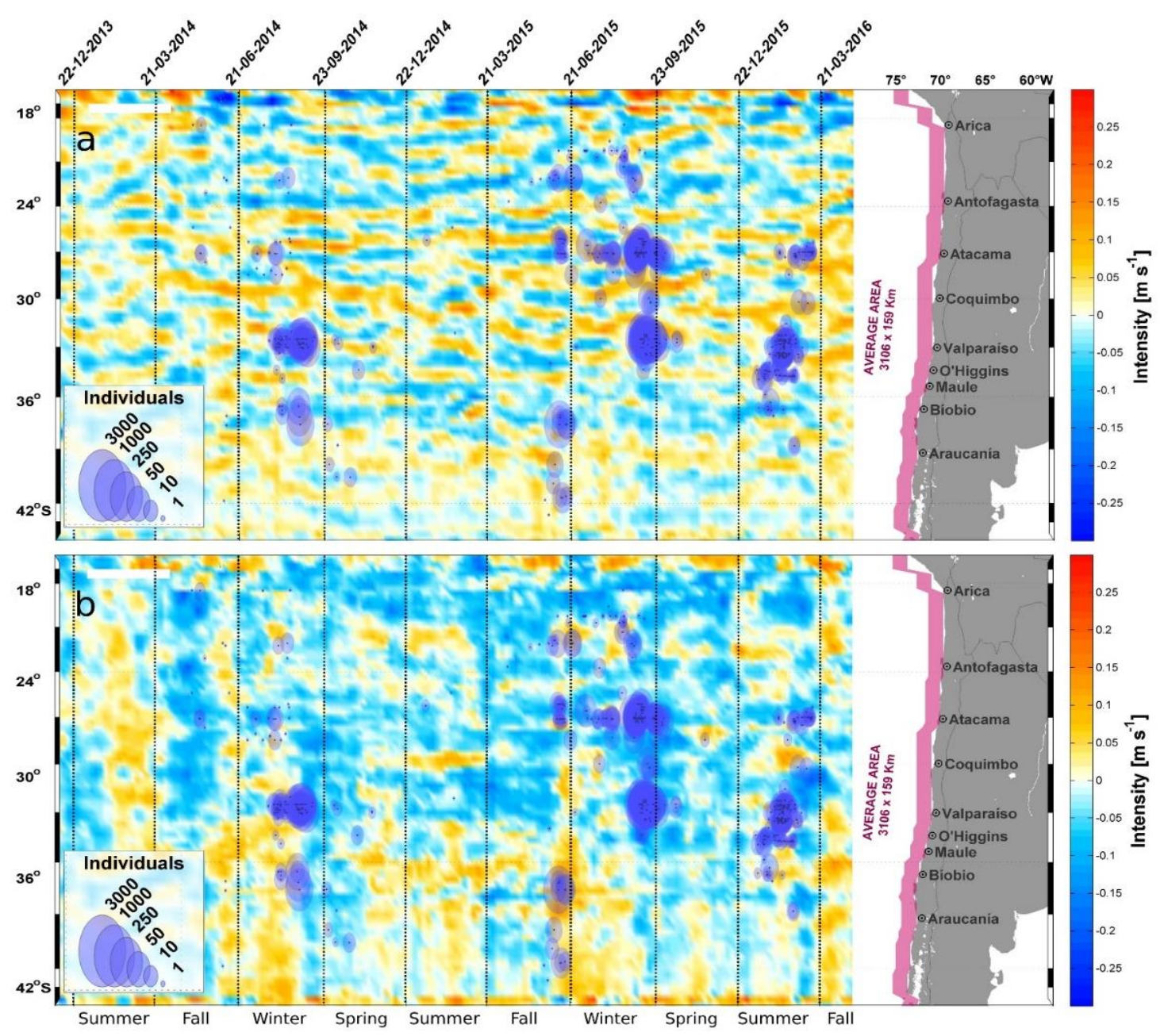

Figure 2. Spatio-temporal sea surface temperature anomaly (weekly mean) extracted from the highlighted (purple) area. Climatology means between 1981 and 2010. Source NOAA Optimum Interpolation (OI) SST V2. Dates correspond to the transition between seasons.

cold period was recorded immediately after a warm period, mostly in the northern part of the study area (to $\left.\sim 36^{\circ} \mathrm{S}\right)$. Afterward, a warm period coincided with the first stranding reports during May and intensified at the end of June. The P. physalis colonies followed a northto-south stranding pattern, with most stranding at the end of the winter (July) associated with the stronger warm conditions (Fig. 2). By contrast, between November 2014 and February 2015, cold periods occurred and were associated with strengthened westerlies and increased upwelling of cold waters along the study area. Few stranded colonies were reported during this cold period (Fig. 2). From February 2015, warm conditions dominated the surface of the SEPO until April 2016, when no more stranded P. physalis was reported during the study period.

The analysis of zonal wind anomaly $\left(\mathrm{m} \mathrm{s}^{-1}\right)$ revealed positive anomalies (wind blowing towards the coast), mostly in the northern area to $\sim 35^{\circ} \mathrm{S}$ at the end of 2013
(Fig. 3). Zonal wind anomalies remained positive for the whole study period only in central $\left(\sim 24\right.$ to $\left.\sim 32^{\circ} \mathrm{S}\right)$ and south-central $\left(\sim 40\right.$ to $\left.\sim 43^{\circ} \mathrm{S}\right)$ Chile (Fig. 4 ). During the late spring and summer of 2015, the anomalies were mostly positive in the study area (Fig. 3). During autumn, winter, and spring of 2015 , the wind patterns were very similar to that in 2014, with positive anomalies in the central and southern areas (Fig. 3). This pattern remained until March 2016. Analysis of meridional wind anomalies $\left(\mathrm{m} \mathrm{s}^{-1}\right)$ showed a more consistent pattern during the study period, with two main areas of positive anomalies (wind blowing to the north) associated with the northern $\left(\sim 18\right.$ to $\left.\sim 25^{\circ} \mathrm{S}\right)$ and central-southern $\left(\sim 32\right.$ to $\left.\sim 42^{\circ} \mathrm{S}\right)$ areas and a continual area of negative anomalies (wind blowing to the south) in central Chile $\left(\sim 24\right.$ to $\left.\sim 32^{\circ} \mathrm{S}\right)$ (Fig. 4). Analysis of surface current (zonal and meridional) anomalies revealed no clear pattern in the study period or area, and they were not considered further (Fig. 2a). 


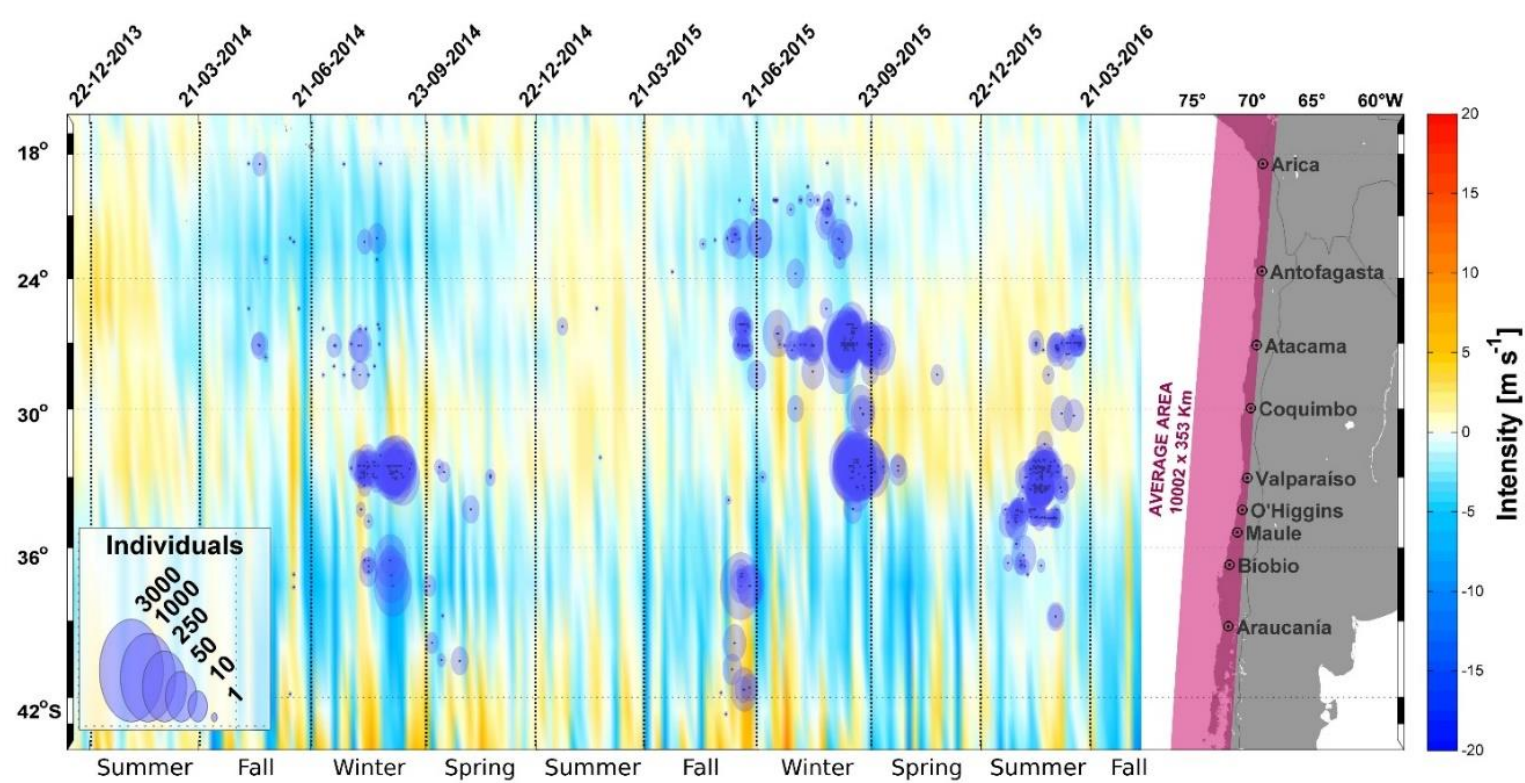

Figure 3. Spatio-temporal zonal surface wind anomaly (daily) extracted from the highlighted (purple) area. Climatology means between 1981 and 2010. Source NCEP-NCAR Reanalysis 1 (NOAA).

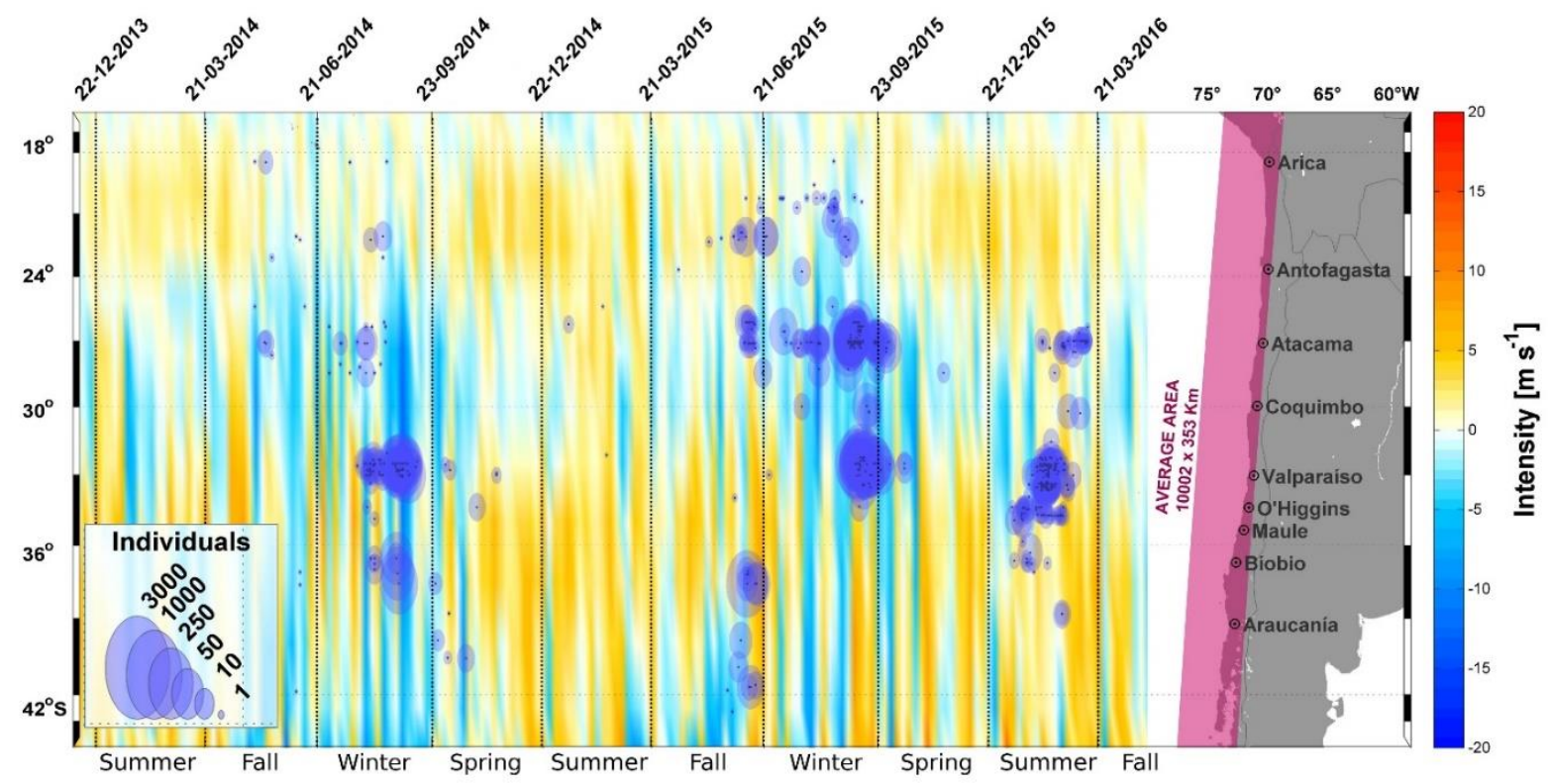

Figure 4. Spatio-temporal meridional surface wind anomaly (daily) extracted from the highlighted (purple) area. Climatology means between 1981 and 2010. Source NCEP-NCAR Reanalysis 1 (NOAA).

The cross-correlation analysis of $P$. physalis with SST showed weak but positive correlations at short time lags ( $\sim 10$ days $)$, for all tested latitudes, with a maximum value of $R=0.4$ in central Chile $\left(35^{\circ} \mathrm{S}\right)$ (Fig. 5a). Both the zonal and meridional surface wind anomalies revealed weak, but positive, correlations in central and northern areas (Figs. 5b-c). At central latitudes $\left(30-35^{\circ} \mathrm{S}\right)$, the correlations tended to be negatives with the meridional surface wind anomalies, but they were not significant (Figs. 5b-c).

The results from the GAMM model showed that, in general, the stranded jellyfish colonies were positively and significantly associated with the zonal component of wind anomaly $(\mathrm{F}=4.32, P<0.05$, Fig. $6 \mathrm{a})$ where positive values (westerly component) increased the number of stranded colonies, reflecting the role of the 

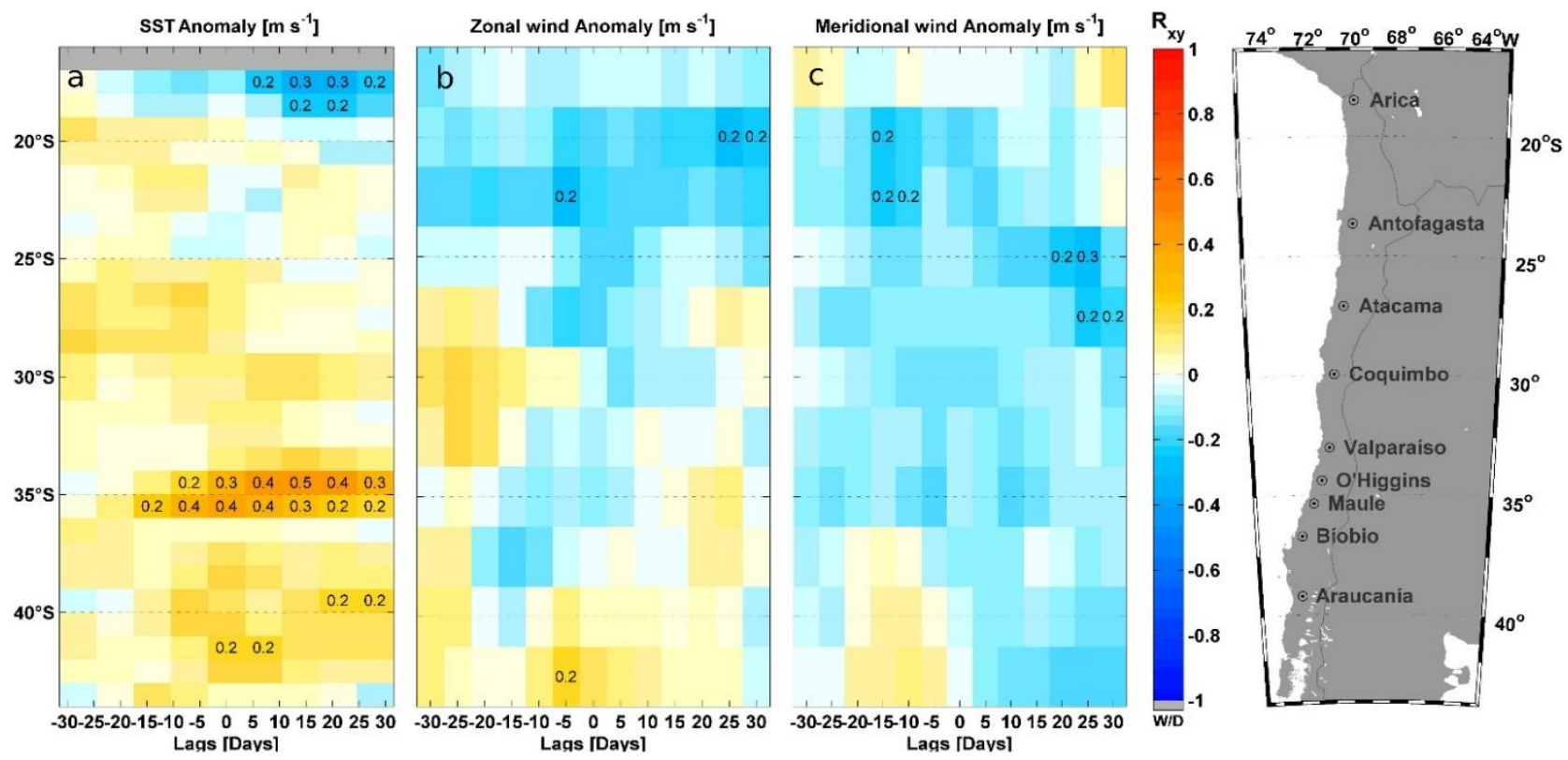

Figure 5. Cross-correlation analysis of the environmental variables. a) Sea surface temperature (SST) anomaly ( $\left.\mathrm{m} \mathrm{s}^{-1}\right)$, b) surface zonal wind anomaly $\left(\mathrm{m} \mathrm{s}^{-1}\right)$, c) surface meridional wind anomaly $\left(\mathrm{m} \mathrm{s}^{-1}\right)$, and Physalia physalis data at different temporal lag (days). Cells with highlighted cross-correlation value were significant $(P<0.05)$.
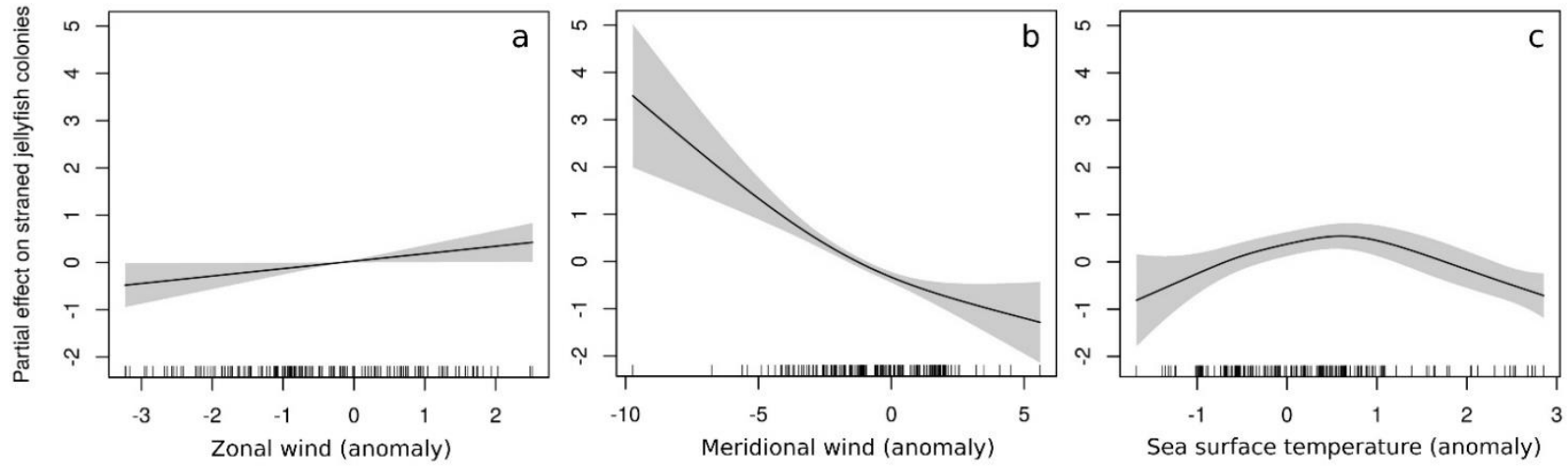

Figure 6. Partial effects of a) zonal wind (anomaly), b) meridional wind (anomaly), and c) sea surface temperature (anomaly) on the numbers of Physalia physalis colonies stranded along the southeastern Pacific Ocean. The continuous black line indicates the GAMM model fit, and in grey, the areas of $95 \%$ confidential intervals of the model.

westerlies to transport colonies to the coast. Also, a negative relationship was found with the anomaly of the meridional wind component $(\mathrm{F}=23.16, P<0.01)$, indicating that winds blowing from north to south increased the numbers of colonies stranded along the coast (Fig. 6b). Finally, SST anomaly also showed a significant relationship with the stranded colonies $(\mathrm{F}=$ $6.19, P<0.01)$, but with a unimodal response, meaning that the initial increase in temperature (as a signal of an ENSO perturbation, Fig. 2) was positively associated with a higher number of jellyfish stranded. However, higher SST values no longer increased the stranded colonies (Fig. 6c).

\section{Effects of Physalia physalis strandings on human activities}

Although during 2014 and 2015, most stranded $P$. physalis occurred during winter, 12 and 14 people were stung, respectively. Those negative interactions were reported only in the north and north-central parts of Chile. Only the first case required hospitalization, probably not because of the medical importance itself but because it was the first case reported, and extra care was associated with handling this patient (Fig. 7a). During 2016, most of the strandings happened during summer, which had higher (negative) repercussions for bathers, with 177 people stung, mostly in south-central 

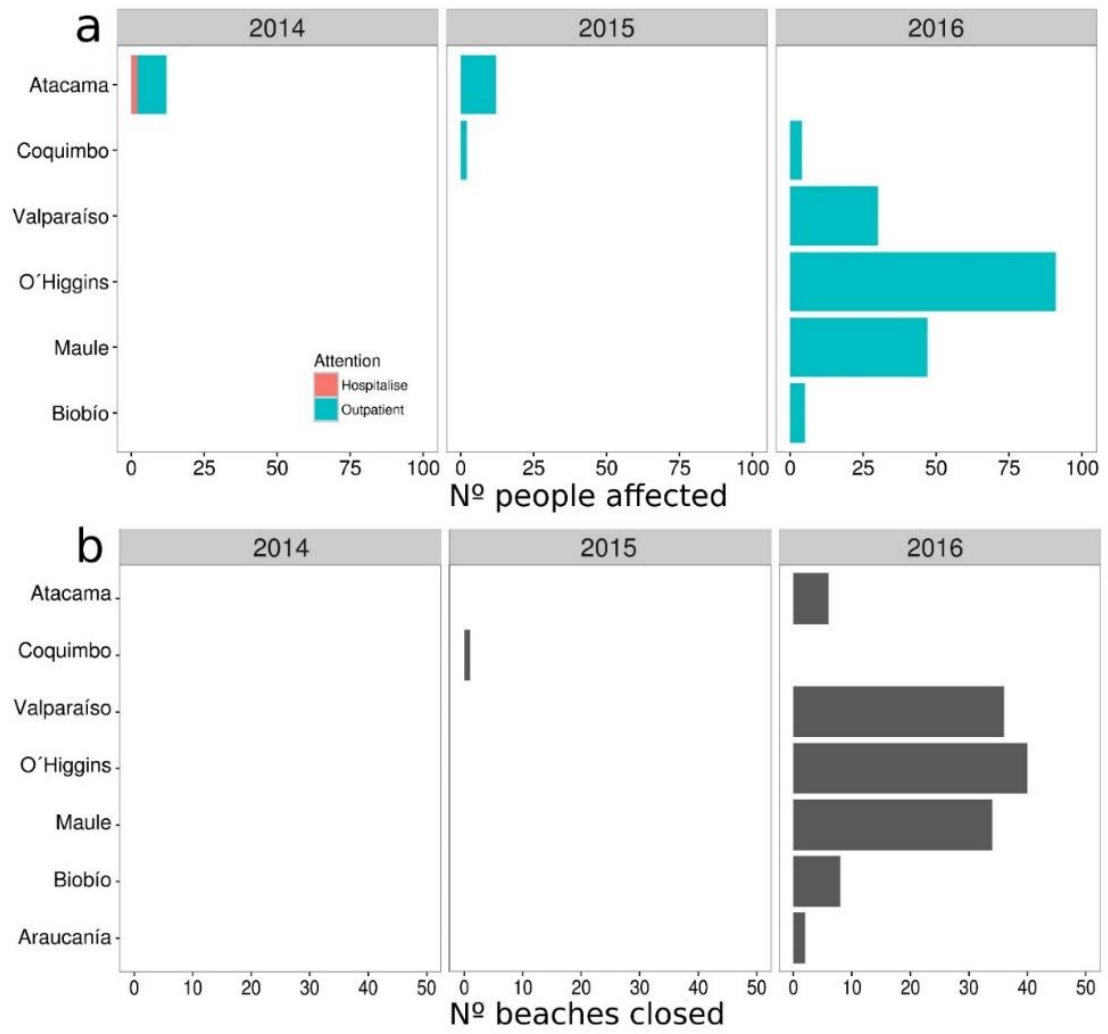

Figure 7. Summary of the effects of Physalia physalis strandings on human activities in different regions of Chile. a) Number of people affected, and b) number of beaches closed, from 2014 to 2016 along the southeastern Pacific Ocean.

Chile (Fig. 7a). Despite the high number of people stung, all were treated as an outpatient. From a coastal management perspective, beaches' closure started only in 2015, with no beach closed in 2014 (Fig. 7b). Most of the closures happened during 2016, with 126 beaches closed, mostly in south-central Chile (Fig. 7b). As far as we know, there were no economic valuations of the impacts of these arrivals.

\section{DISCUSSION}

\section{Spatio-temporal distribution of Physalia physalis strandings}

Typically, colonies of $P$. physalis strandings occur at irregular time intervals and in low magnitudes not exceeding hundreds of colonies (Bingham \& Albertson, 1974; Brito, 2002; Pontin et al., 2011; Prieto et al., 2015). We characterized mass strandings of $P$. physalis, with more than 40,000 stranded colonies along more than $2,600 \mathrm{~km}$ of the southeastern Pacific Ocean (SEPO) during three consecutive years.

Stranded jellyfish data have been used as a source of information for analyzing, from a population to a community level, their spatio-temporal dynamics
(Bingham \& Albertson, 1974; Houghton et al., 2007; Bernard et al., 2011; Canepa et al., 2014; Thiel et al., 2014). Stranding data are useful when the identification of the species can be made easily by the participants; thus, the easy identification of $P$. physalis allows nonscientific surveys to be used correctly (Houghton et al., 2007; Pontin et al., 2011; Ferrer et al., 2015). This study represents an agreement between the Chilean Navy, with more than 20 Port Authorities working along the SEPO, and the Chilean Ministry of Health, that allowed us access to valuable information about the spatiotemporal dynamics of massive strandings of $P$. physalis colonies and their coastal management (Fig. S1).

All previous reports of stranded P. physalis colonies along the Chilean coast and oceanic islands were anecdotal and, when large (hundreds), were always during summer and lasting only one season (Table 1). The strandings reported here are remarkable for their magnitudes ( $\leq 44,683$ colonies) and by durations that accounted for three years of continual strandings of colonies along a significant length of the Chilean coastline. Additionally, most strandings occurred during the winter season (Fig. 1). In non-scientific survey data, as for citizen science, a lack of information 
may be due to a lack of effort during low tourist seasons (Pontin et al., 2011). In the present study, however, the monitoring program was continuous, and the reports accurately reflected the spatio-temporal dynamics of stranded $P$. physalis colonies.

P. physalis's northernmost record along the Chilean coast was previously reported at $26^{\circ} 10^{\prime} \mathrm{S}$ (Araya et al., 2016). During 2015 P. physalis was reported $\sim 870 \mathrm{~km}$ further north at $18^{\circ} 26^{\prime} 44.09^{\prime \prime} \mathrm{S}$, establishing a new northern record for $P$. physalis stranded in Chile. Its distribution extended further north from several media reports of stranded or near-shore colonies along Perú to Colombia in 2015. Similarly, the southernmost record in our study at $42^{\circ} 37^{\prime} 59.9^{\prime \prime} \mathrm{S}$ extended its known southern distribution by more than $250 \mathrm{~km}$. Dispersion and transport by surface winds and currents certainly are important in the at-sea and stranded distributions of P. physalis (Bingham \& Albertson, 1974; Pontin et al., 2011; Ferrer et al., 2015). The geographical extents of the reported stranded events were not homogeneous. The central and south-central areas were the most affected, coinciding with previous stranded colonies' records along the SEPO (Brito, 2002).

\section{Oceanographic and meteorological conditions associated with the stranding events}

The environmental variables analyzed showed clear conditions associated with an "El Niño" Southern Oscillation ENSO event (Battisti \& Sarachik, 1995), specifically, a weakening of the westerlies associated with warm surface ocean conditions. This ENSO event (2015-2016) was one of the strongest since records began (Jacox et al., 2016); nevertheless, surface oceanographic patterns also showed some areas with negative SST areas, indicating cold water upwelled by westerly winds. This counterintuitive pattern was previously reported for this ENSO event by Dunkerton (2016). During late 2013 and early 2014, positive SST and positive zonal wind anomalies were associated with the beginning of the stranding events (Figs. 2-3). No other clear associations between positive SST and zonal wind anomalies were detected until the winter of 2015 when most stranding colonies arrived at the coast and the oceanic islands. Generalized additive mixed models showed the importance of wind forcing in the transportation of the colonies to the coast in agreement with Pontin et al. (2011) associated with a period of positive water temperature anomalies. The observed oceanographic conditions representative of a spatiotemporal coupling of positive SST and zonal wind anomalies may indicate favorable conditions for colonies of $P$. physalis off-shore and for transporting the colonies to the shore (Dunkerton, 2016).
Surface wind and currents influence $P$. physalis' dispersion, and as a pleustonic organism, however, colonies can modify their drag and relative speed of drift by altering the length of tentacles and shape of the pneumatophore, respectively (Iosilevskii \& Weihs, 2009). For this reason, a decoupling between the detection of stranded colonies and the oceanographic conditions may emerge, visualized as a time lag in the correlative analysis (Pontin et al., 2011). During the present study, the temporal lag varied between the oceanographic variables and latitude, and a positive association between the stranded colonies and SST and zonal wind anomalies within time lags ( $\sim 10$ days) only occurred in central Chile $\left(\sim 30\right.$ to $\left.\sim 35^{\circ} \mathrm{S}\right)$ (Figs. 5a-b). Thus, the observed pattern of massive stranding of $P$. physalis in central Chile can be explained by the prevalence of positive zonal wind anomalies through the study period and the warmer conditions associated with the ENSO perturbation latitudes. The effects of large-scale climate events may affect jellyfish around the world. The biomass of another jellyfish (Chrysaora plocamia) increased during warming inter-decadal (El Viejo) and interannual (El Niño) climate events in Peru (1972-2014) and had begun to increase during 20122014, the last years analyzed by Quiñones et al. (2015). Another pleustonic species, Velella velella, also had massive strandings all along with North America's west coast in 2013 and 2014, the last years analyzed by Purcell et al. (2015). The blooms of $V$. velella also were unusually large in the North Pacific and the Mediterranean in 2013 and 2014, as were blooms of some other species there and in other locations (Purcell et al., 2015). The weakening of the shelf front in the NW Mediterranean results in many Pelagia noctiluca medusae being driven into the northeast Spanish coast by winds from the southeast (Canepa et al., 2014); they suggested that large-scale environmental factors could be responsible. Strandings of $V$. velella and $P$. physalis have co-occurred in the Chilean coastline (Moyano \& Valdovinos, 1984). Thus, the effects of climate forcing like the ocean-atmospheric coupling process (e.g., ENSO, Pacific Decadal Oscillation, PDO), longer regimen shifts (e.g., El Viejo / La Vieja), the sea surface temperature trend associated with the global climate change, wind and current patterns, and disruptions, among others could be vast and affect many species.

\section{Effects of Physalia physalis strandings on human activities}

The possibility of forecasting $P$. physalis strandings from wind and current data is of global interest for human health, mainly by the wide distribution of this species, so the relation with oceanographic variables (e.g., wind, currents, SST) will help to minimize 
accidents and economic losses for tourism. There are about 150 million jellyfish stings worldwide each year, and $P$. physalis is responsible for most of these stings, with symptoms including intense pain, permanent scarring, gastrointestinal, muscular, cardiac, neurological, and allergic reactions (Cegolon et al., 2013). The environmental and species data needed for such predictions are often freely available, as in the Bay of Biscay, where $P$. physalis transport at sea was modeled using hourly surface currents from the Regional Ocean Modelling System and winds from the Weather Research and Forecasting model (Ferrer et al., 2015), and stranding data from citizen science programs, as in our study.

In Chile, Brito (2002) noted 165 people stung by $P$. physalis despite a low number of the stranded colonies. During our study, only 203 people (men, women, and children equally; data not shown) were stung by thousands of stranded colonies (Fig. 6a). This low incidence was due to the high number of beaches closed and the proper management of the situation thanks to the excellent surveillance and agreement between the Chilean Navy and the Chilean Ministry of Health compared to other reports (Brito, 2002). This situation led to continuous monitoring of the beaches, suitable protocols for removing the stranded colonies, and rapid beach closure after only three colonies stranded per beach (Fig. S1b).

\section{CONCLUSIONS}

Physalia physalis is a globally-distributed species with a dangerous sting and potentially severe adverse effects on human health and fish populations (Purcell, 1984; Burnett et al., 1994; Cegolon et al., 2013; Haddad Jr. et al., 2013; Mapstone, 2015). Historically, P. physalis's massive strandings in Chile were rare; however, our report of recent multi-year massive strandings of $P$. physalis suggests that their numbers are increasing. The response of $P$. physalis stranded colonies to the environmental variables directly related to an ENSO and the potential effect of SST in future scenarios over the asexual reproduction of several jellyfish species and also future scenarios for the ENSO dynamics can be indicating a favorable scenario for this species shortly. An unwelcome scenario due to increasing interactions with humans at the coast and with fish can harm local fish stocks and economic losses in the tourism sector. Because $P$. physalis lives at the ocean surface and are driven by winds to the coast, are easily recognized, and sting painfully, they are excellent subjects for citizen science projects. We used beach strandings of $P$. physalis and environmental data to demonstrate that the massive strandings in 2014-2016 were affected by wind and temperature conditions associated with an ENSO. Our study illustrates the possibility of using the species $P$. physalis as an indicator species for large-scale disturbances such as the ENSO event and its stranding dynamics as a possible effect of major disturbances such as global climate change. We also demonstrate the utility of collaborations among scientists and public organizations to promote large-scale and long-term monitoring programs that can result in a better understanding of some biological processes and predictive tools of dangerous marine animals that affect fish populations and human health.

\section{ACKNOWLEDGMENTS}

Special thanks must be given to Captain Rodrigo Zambrano (Head of the Aquatic Environment Division, Regional Direction of the Maritime Territory), to Bruno Rodríguez and Eugenia Valdebenito (Regional Direction of the Maritime Territory), to Andrea Rivera (Undersecretary of Public Health, Ministry of Health) and Guido Martínez (Department of Environmental Health, Ministry of Health), for their invaluable effort in the coordination and transfer of information among the responsible partners of the "Portuguese Man of War Working Group." The National Commission for Scientific and Technological Research -CONICYT (PAI/82140034, A. Canepa) supported this work.

\section{REFERENCES}

Araya, J.F., Aliaga, J.A. \& Araya, M.E. 2016. On the distribution of Physalia physalis (Hydrozoa: Physaliidae) in Chile. Marine Biodiversity, 46: 731-735.

Battisti, D.S. \& Sarachik, E.S. 1995. Understanding and predicting ENSO. Reviews of Geophysics, 33: 13671376.

Baumann, S. \& Schernewski, G. 2012. Occurrence and public perception of jellyfish along the German Baltic coastline. Journal of Coastal Conservation, 16: 555566.

Bernard, P., Berline, L. \& Gorsky, G. 2011. Long term (1981-2008) monitoring of the jellyfish Pelagia noctiluca (Cnidaria, Scyphozoa) on Mediterranean Coasts (Principality of Monaco and French Riviera). Journal of Oceanography, Research and Data, 4: 1-10.

Bingham, F.O. \& Albertson, H.D. 1974. Observations on beach strandings of the Physalia (Portuguese-Man-ofWar) community. Veliger, 17: 220-224.

Box, G.E.P., Jenkins, G.M., Reinsel, G.C. \& Ljung, G.M. 2005. Time series analysis: forecasting and control. Wiley Publishing, New Jersey. 
Brito, J.L., 2002. Physalia physalis (Linnaeus, 1758) (Cnidaria, Hydrozoa, Siphonophora) en la costa central de Chile. Noticiario Mensual del Museo Nacional de Historia Natural, 349: 6-8.

Brotz, L., Cheung, W.W.L., Kleisner, K., Pakhomov, E. \& Pauly, D. 2012. Increasing jellyfish populations: trends in large marine ecosystems. Hydrobiologia, 690: 3-20.

Burnett, J.W., Fenner, P.J., Kokelj, F. \& Williamson, J.A. 1994. Serious Physalia (Portuguese man o'war) stings: implications for scuba divers. Journal of Wilderness Medicine, 5: 71-76.

Canepa, A., Fuentes, V., Sabatés, A., Piraino, S., Boero, F. \& Gili, J.-M. 2014. Pelagia noctiluca in the Mediterranean Sea. In: Pitt, K.A. \& Lucas, C.H. (Eds.). Jellyfish blooms. Springer Science+Business Media, Dordrecht, pp. 237-265.

Cegolon, L., Heymann, W.C., Lange, J.H. \& Mastrangelo, G. 2013. Jellyfish stings and their management: a review. Marine Drugs, 11: 523-550.

Condon, R.H., Graham, W.M., Duarte, C.M., Pitt, K.A., Lucas, C.H., Haddock, S.H., et al. 2012. Questioning the rise of gelatinous zooplankton in the world's oceans. Bioscience, 62: 160-169.

Dunkerton, TJ, 2016. The quasi-biennial oscillation of 2015-16: Hiccup or death spiral? Geophysical Research Letters, 43: 10547-10552.

Fagetti, E.G., 1958. Nota sobre Physalia physalis L. procedente de la Isla de Pascua. Revista de Biología Marina, 7: 188-190.

Ferrer, L., Zaldua-Mendizaba, N., Del Campo, A., Franco, J., Mader, J., Cotano, U., et al. 2015. Operational protocol for the sighting and tracking of Portuguese man-of-war in the southeastern Bay of Biscay: observations and modelling. Continental Shelf Research, 95: 39-53.

Fleming, N.E.C., Harrod, C. \& Houghton, J.D.R. 2013. Identifying potentially harmful jellyfish blooms using shoreline surveys. Aquaculture Environment Interactions, 4: 263-272.

Graham, W.M., Pagès, F. \& Hamner, W.M. 2001. A physical context for gelatinous zooplankton aggregations: a review. Hydrobiologia, 451: 199-212.

Haddad Jr., V., Virga, R., Bechara, A., Lang da Silveira, F. \& Morandini, A.C. 2013. An outbreak of Portuguese man-of-war (Physalia physalis - Linnaeus, 1758) envenoming in Southeastern Brazil. Revista da Sociedade Brasileira de Medicina Tropical, 46: 641644.

Houghton, J.D.R., Doyle, T.K., Davenport, J., Lilley, M.K.S., Wilson, R.P. \& Hays, G.C. 2007. Stranding events provide indirect insights into the seasonality and persistence of jellyfish medusae (Cnidaria: Scyphozoa). Hydrobiologia, 589: 1-13.
Iosilevskii, G. \& Weihs, D. 2009. Hydrodynamics of sailing of the Portuguese man-of-war Physalia physalis. Journal of the Royal Society Interface, 6: 613-626.

Jacox, M.G., Hazen, E.L., Zaba, K.D., Rudnick, D.L., Edwards, C.A., Moore, A.M. \& Bograd, S.J. 2016. Impacts of the 2015-2016 El Niño on the California Current System: early assessment and comparison to past events. Geophysical Research Letters, 43: 70727080.

Leloup, E. 1935. Hydropolypes calyptoblastiques et siphonophores récoltés au cours de la Croisière (19341935) du navire-école Belge «Mercator». Mémoires du Musée Royal d'Histoire Naturelle de Belgique, 11: $1-6$.

Licandro, P., Conway, D.V.P., Yahia, D.M.N., Fernandez de Puelles, M.L., Gasparini, S., Hecq, J.H., Tranter, P. \& Kirby, R.R. 2010. A blooming jellyfish in the northeast Atlantic and Mediterranean. Biological Letters, 6: 688-691.

Mapstone, G.M. 2014. Global diversity and review of Siphonophorae (Cnidaria: Hydrozoa). Plos One, 9: e87737.

Mapstone, G.M. 2015. Systematics of siphonophores. In: Gopalakrishnakone, P. \& Malhotra, A. (Eds.). Evolution of venomous animals and their toxins. Springer, Amsterdam, pp. 319-366.

Mianzan, H., Purcell, J.E. \& Frost, J.R. 2012. Preface: jellyfish blooms: interactions with humans and fisheries. Hydrobiologia, 690: 1-2.

Molina, J.I. 1782. Saggio sulla storia naturale del Chili. Stamperia di S. Tommaso d'Aquino, Bologna.

Moyano, H.I. \& Valdovinos, C. 1984. Sobre Physalia physalis (Linné, 1758) y Velella spirans Forskal, 1775, Provenientes de la X Región de Chile (Cnidaria, Hydrozoa). Boletín de la Sociedad de Biología de Concepción, 55: 171-174.

Oliveira, O.M.P., Miranda, T.P., Araujo, E.M., Ayón, P., Cedeño-Posso, C.M., Cepeda-Mercado A.A., et al. 2016. Census of Cnidaria (Medusozoa) and Ctenophora from South American marine waters. Zootaxa, 4194: 1-254.

Pontin, D.R. \& Cruickshank, R.H. 2012. Molecular phylogenetics of the genus Physalia (Cnidaria: Siphonophora) in New Zealand coastal waters reveals cryptic diversity. Hydrobiologia, 686: 91-105.

Pontin, D.R., Schliebs, S., Worner, S.P. \& Watts, M.J. 2011. Determining factors that influence the dispersal of a pelagic species: a comparison between artificial neural networks and evolutionary algorithms. Ecological Modelling, 222: 1657-1665. 
Prieto, L., Macías, D., Peliz, A. \& Ruiz, J. 2015. Portuguese Man-of-War (Physalia physalis) in the Mediterranean: a permanent invasion or a casual appearance? Scientific Reports, 5: 11545.

Purcell, J.E. 1984. Predation on fish larvae by Physalia physalis, the Portuguese man of war. Marine Ecology Progress Series, 19: 189-191.

Purcell, J.E. 2009. Extension of methods for jellyfish and ctenophore trophic ecology to large-scale research. Hydrobiologia, 616: 23-50.

Purcell, J.E. \& Arai, M.N. 2001. Interactions of pelagic cnidarians and ctenophores with fish: a review. Hydrobiologia, 451: 27-44.

Purcell, J.E., Atienza, D., Fuentes, V., Olariaga, A., Tilves, U., Colahan, C. \& Gili, J.-M. 2012. Temperature effects on asexual reproduction rates of scyphozoan polyps from the NW Mediterranean Sea. Hydrobiologia, 690: 169-180.

Purcell, J.E., Milisenda, G., Rizzo, A., Carrion, S.A., Zampardi, S., Airoldi, S., et al. 2015. Digestion and predation rates of zooplankton by the pleustonic hydrozoan Velella velella and widespread blooms in 2013 and 2014. Journal of Plankton Research, 37: 1056-1067.
Quiñones, J., Mianzan, H., Purca, S., Robinson, K.L., Adams, G.D. \& Acha, M.E. 2015. Climate-driven population size fluctuations of jellyfish (Chrysaora plocamia) off Peru. Marine Biology, 162: 2339-2350. doi: $10.1007 / \mathrm{s} 00227-015-2751-4$

R Core Team. 2017. R: a language and environment for statistical computing. R Foundation for Statistical Computing, Vienna. [https://www.R-project.org/]. Reviewed: December 12, 2019.

Thiel, M., Penna-Díaz, M.A., Luna-Jorquera, G., Salas, S., Sellanes, J. \& Stotz, W. 2014. Citizen scientists and marine research: volunteer participants, their contributions, and projection for the future. Oceanography and Marine Biology, 52: 257-314.

Wood, S.N. 2004. Stable and efficient multiple smoothing parameter estimation for generalized additive models. Journal of the American Statistical Association, 99: 673-686.

Zuur, A.F., Savaliev, A.A. \& Ieno, E.N. 2014. A beginner's guide to generalized additive mixed models with $\mathrm{R}$. Highland Statistics, Newburgh.

Received: 5 March 2020; Accepted: 11 July 2020

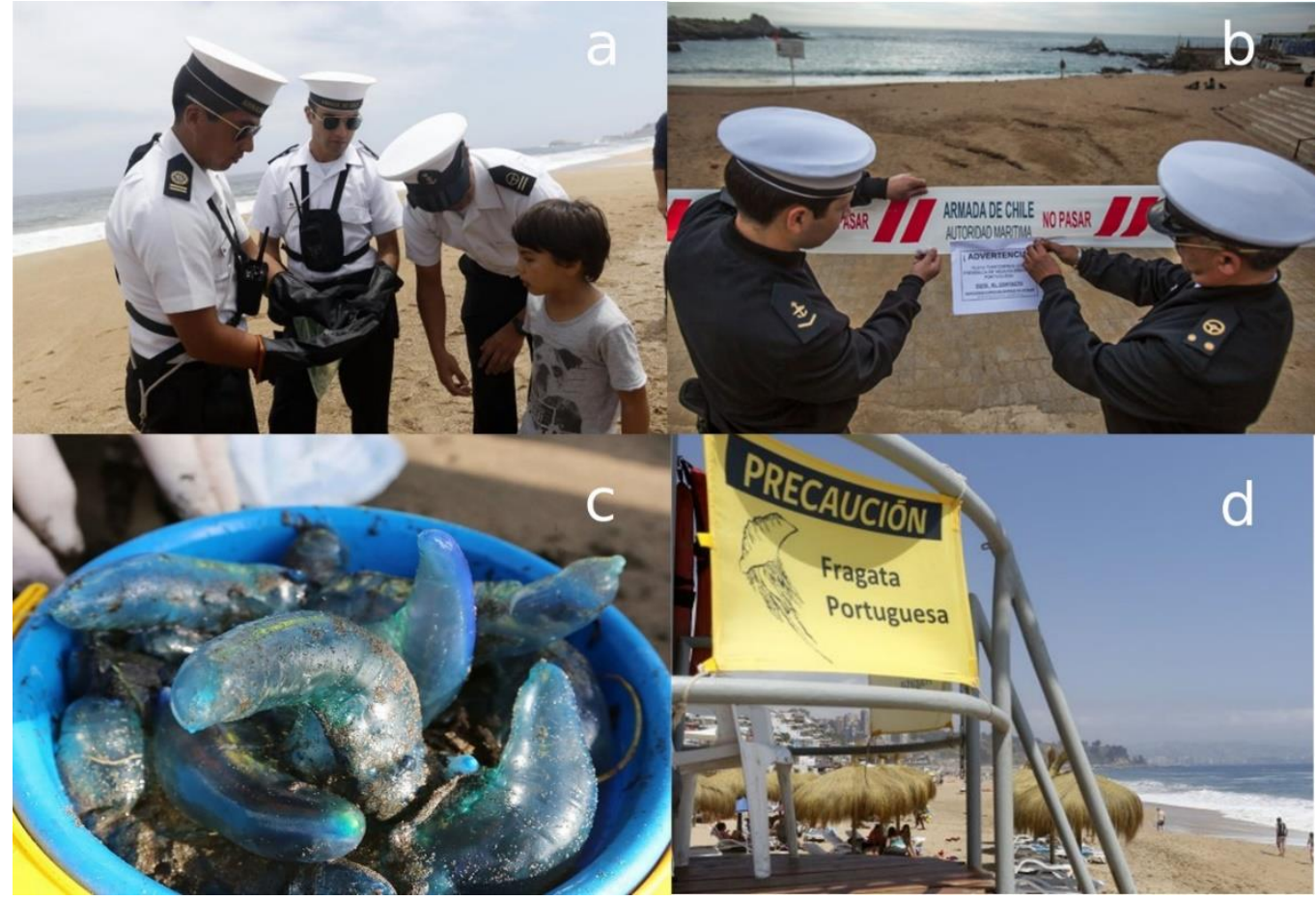

Figure Supplementary 1. Monitoring program of Physalia physalis along the Chilean coasts. a) Chilean Navy inspectors warning to a (young) tourist about the appearance and danger of the species even after stranded, b) beach closure by the Chilean Navy authorities, c) stranded colonies of $P$. physalis been removed from the beach, and d) warning flag of $P$. physalis presence deployed on a beach restaurant. 